\title{
Pembesaran Gaya Dalam dan Rasio Kekuatan Elemen Struktur Baja untuk Berbagai Koefisien Modifikasi Respon $(R)$
}

\author{
WAHYU SATRIA KOMARA, KAMALUDIN
}

\author{
Jurusan Teknik Sipil Institut Teknologi Nasional Bandung \\ Email: Wsatria99@gmail.com
}

\begin{abstract}
ABSTRAK
Perencanaan struktur bangunan yang elastis membuat dimensi struktur yang di desain menjadi lebih besar sehingga biaya pembangunan struktur menjadi meningkat. Struktur bangunan harus di desain dengan suatu konsep tertentu sehingga bangunan tersebut dapat menahan beban yang terjadi secara efisien. Perencanaan struktur bangunan gedung dengan menggunakan koefisien modifikasi respon $(R)$ ialah merencanakan bangunan untuk mengalami proses plastifikasi pada elemen struktur ketika terjadi gempa. Penelitian ini membandingkan model struktur bangunan dari rangka baja yang terdiri dari 10 lantai, dengan variasi koefisien modifikasi respon $(R)$ yaitu, $R=3 ; 3,5 ; 4,5 ; 5 ; 6$; 7; dan 8. Ketujuh model ini juga di dianalisis sesuai dengan sistem penahan gaya seismiknya. Analisis pada penelitian ini menggunakan program ETABS2015. Dari hasil analisis, diperoleh bahwa Semakin kecil nilai koefisien modifikasi respon ( $R$ ) yang digunakan mempengaruhi rasio lentur yang terjadi. Perbesaran lentur pada kolom 18 (C18) ketika nilai $R=3$ sebesar $52,47 \%$.
\end{abstract}

Kata kunci: koefisien modifikasi respon (R), daktilitas, pembesaran gaya dalam

\begin{abstract}
Planning an elastic building structure makes the dimensions and designed structures larger and it can increases the cost of the construction itself. The building structures must be designed with a certain concept so, that the building can withstand the loads efficiently. A structure planning using the response modification coefficient $(R)$ is to plan the building to experience a process of plasticization of the structural elements during an earthquake. This study compares the building structure model of a steel frame consisting of 10 floors, with variation in the modification coefficient of response $(R)$ from $R=3 ; 3,5 ; 4,5$; 5; 6; 7; until 8 . The seven models are also analysed according to the seismic force retaining system. The analysis in this study using the ETABS2015 program. From the results of the analysis, it was found that the smaller the value of the $R$ response modification coefficient used will affects the bending ratio that occurs. The flexural force when the value of $R=3$ in column 18 (C18) is $52.47 \%$.
\end{abstract}

Keywords: response modification coeffient, ductility, inner force enlargement 


\section{PENDAHULUAN}

Pembangunan gedung bertingkat tinggi di berbagai kota besar di Indonesia semakin meningkat. Hal ini merupakan suatu bentuk upaya untuk memenuhi kebutuhan fasilitas ruang yang disebabkan oleh keterbatasan lahan. Namun, dilihat dari posisi geografis Indonesia yang diapit oleh dua samudera yaitu, samudera pasifik dan samudera hindia dan juga posisi Indonesia yang berada pada pertemuan tiga lempeng tektonik menyebabkan gedung-gedung tersebut rawan terhadap gempa bumi.

Perkembangan diberbagai ilmu pengetahuan dan terknologi di bidang struktur tahan gempa telah membentuk suatu aturan yang harus diikuti sehingga struktur yang direncanakan sesuai dengan kriteria struktur tahan gempa.

Suatu konstruksi bisa disebut tahan terhadap gempa jika konstruksi tersebut mampu menahan beban gempa baik secara horizontal maupun vertikal. Sehingga tidak terjadi kerusakan parah yang menyebabkan struktur bangunan tersebut runtuh.

Pemilihan nilai koefisien modifikasi respon $(R)$ dapat menentukan seberapa besar gaya dalam yang dihasilkan. Oleh karena itu, dibutuhkan penelitian tentang pengaruh nilai koefisien modifikasi respon $(R)$ terhadap pembesaran gaya dalam serta pengaruhnya terhadap penggunaan elemen-elemen konstruksi yang menentukan kekuatan pada struktur tersebut. Penelitian ini juga ditujukkan untuk membantu para perencana memprediksi besarnya beban yang akan dipikul oleh struktur yang didesain dengan memperhitungkan beban gempa.

\section{TINJAUAN PUSTAKA}

\subsection{Daktilitas}

Daktilitas adalah kemampuan suatu struktur unutk mengalami simpangan pasca-elastik yang besar secara berulang kali dan bolak-balik akibat beban gempa di atas beban gempa yang menyebabkan terjadinya pelelehan pertama, sambil mempertahankan kekuatan dan kekakuan yang cukup, sehingga struktur gedung tersebut tetap berdiri, walaupun sudah berada dalam kondisi di ambang keruntuhan (Badan Standardisasi Nasional, 2012).

\subsection{Pembebanan}

Beban yang digunakan pada penelitian ini yaitu:

1. Beban mati

Beban mati adalah beban yang beradap pada posisi yang sama setiap saat dengan besar yang konstan. Beban ini merupakan berat sendiri struktur termasuk beban lain yang melekat secara permanen seperti, dinding, lantai, plafon, tangga, atap, plumbing, dll.

2. Beban hidup

Beban hidup ialah beban penggunaan suatu gedung yang didalamnya termasuk beban lantai yang berasal baik dari barang, mesin, orang yang dapat berpindah sehingga mengakibatkan perubahan dalam pembebanan pada lantai dan atap.

3. Beban gempa

Beban gempa adalah semua beban statik ekivalen yang bekerja pada struktur yang menirukan pengaruh dari tanah akibat gempa.

\subsection{Preliminary Design}

Perencanaan desain tebal pelat didasarkan pada SNI 2847:2013 persamaan yang digunakan untuk menghitung desain pelat adalah sebagai berikut:

1. Desain Pelat Beton 
a. Jika $0,2 \leq a_{f m} \leq 2$, maka tebal pelat dapat dihitung menggunakan Persamaan 1 .

$$
h=\frac{l_{n}\left(0,8+\frac{f_{y}}{1400}\right)}{36+5 \beta\left(\alpha_{f m}-0,2\right)}>125 \mathrm{~mm}
$$

b. Jika $a_{f m} \geq 2$, maka tebal pelat dapat dihitung menggunakan Persamaan 2 .

$$
h=\frac{l_{n}\left(0,8+\frac{f y}{1400}\right)}{36+9 \beta}>90 \mathrm{~mm}
$$

C. Jika $a_{f m} \leq 0,2, \mathrm{~h}=$ ketebalan minimum pelat tanpa balok dalam dapat dilihat pada

\begin{tabular}{|c|c|c|c|c|c|c|}
\hline \multirow{3}{*}{ 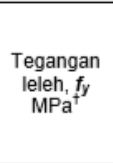 } & \multicolumn{3}{|c|}{ Tanpa penebalan $^{2}$} & \multicolumn{3}{|c|}{ Dengan penebalan ${ }^{\mp}$} \\
\hline & \multicolumn{2}{|c|}{ Panel eksterior } & \multirow[t]{2}{*}{$\begin{array}{c}\text { Panel } \\
\text { interior }\end{array}$} & \multicolumn{2}{|c|}{ Panel eksterior } & \multirow[t]{2}{*}{ Panel interior } \\
\hline & $\begin{array}{c}\text { Tanpa balok } \\
\text { pinggir }\end{array}$ & $\begin{array}{c}\text { Dengan } \\
\text { balok pinggir }\end{array}$ & & $\begin{array}{l}\text { Tanpa } \\
\text { balok } \\
\text { pinggir }\end{array}$ & $\begin{array}{c}\text { Dengan } \\
\text { balok pinggir }{ }^{5}\end{array}$ & \\
\hline 280 & $\ell_{n} / 33$ & $\ell_{n} / 36$ & $\ell_{n} / 36$ & $\ell_{n} / 36$ & $\ell_{n} / 40$ & $\ell_{n} / 40$ \\
\hline 420 & $\ell_{n} / 30$ & $\ell_{n} / 33$ & $\ell_{n} / 33$ & $\ell_{n} / 33$ & $\ell_{n} / 36$ & $\ell_{n} / 36$ \\
\hline 520 & $\ell_{n} / 28$ & $\ell_{n} / 31$ & $\ell_{n} / 31$ & $\ell_{n} / 31$ & $\ell_{n} / 34$ & $\ell_{n} / 34$ \\
\hline \multicolumn{7}{|c|}{$\begin{array}{l}\text { Untuk konstruksi dua arah, } \ell_{n} \text { adalah panjang bentang bersih dalam arah panjang, diukur muka ke muka tumpuan pada } \\
\text { pelat tanpa balok dan muka ke muka balok ataut tumpuan lainnya pada kasus yang lain. } \\
\text { pentuk } f_{y} \text { antara nilai yang diberikan dalam tabel, tebal minimum harus ditentukan dengan interpolasi linier. } \\
\text { Fanel drop didefinisikan dalam } 13.2 .5 \text {. } \\
\text { Pelat dengan balok di antara kolom kolomnya di sepanjang tepi eksterior. Nilai } a r \text { untuk balok tepi tidak boleh kurang } \\
\text { dari } 0,8 \text {. }\end{array}$} \\
\hline
\end{tabular}
Gambar 1.

Gambar 1. Tebal minimum pelat tanpa balok interior

(Sumber: SNI 2847:2013)

halmana:

$f_{y} \quad=$ tegangan leleh baja [MPa],

$h=$ tebal pelat [m],

$l_{n} \quad=$ panjang bentang bersih [m],

$\beta \quad=$ rasio dimensi panjang terhadap pendek,

$\alpha_{f m}=$ nilai rata-rata $\alpha$ untuk semua balok pada tepi panel.

2. Desain Kolom Baja

Perhitungan dimensi kolom baja berdasarkan SNI 1729:2015, antara lain:

a. Jika 0,2 $\leq a_{f m} \leq 2$, maka tebal pelat dapat dihitung menggunakan Persamaan 1.

i. Jika $\frac{K L}{r}>4,71 \sqrt{\frac{E}{f y}}$, maka elastis

ii. Jika $\frac{K L}{r}<4,71 \sqrt{\frac{E}{f y}}$, maka inelastis

halmana:

$K=$ faktor panjang efektif,

$E=$ modulus elastisitas baja [MPa],

$L \quad=$ panjang komponen struktur [mm].

iii. Jika inelastis maka menggunakan Persamaan 3.

$$
F_{c r}=\left(0,658^{\frac{f_{y}}{f_{e}}}\right) f_{y}
$$

iv. Jika elastis maka menggunakan Persamaan 4.

$$
F_{c r}=0,877 f_{e}
$$


halmana:

$f_{e}=$ tegangan tekuk elastis yang dapat dihitung menggunakan Persamaan 5

$$
f_{e}=\frac{\pi^{2} E}{\left(\frac{k L}{r}\right)^{2}}
$$

v. Cek kapasitas kolom menggunakan Persamaan 6.

$$
\emptyset R_{n}=\varnothing F_{c r} * A_{g}
$$

halmana:

$\emptyset \quad=$ faktor reduksi,

$R_{n}=$ kekuatan material $[\mathrm{kN} / \mathrm{m}]$,

$F_{c r}=$ tegangan kritis [MPa],

$A_{g}=$ luas penampang $\left[\mathrm{mm}^{2}\right]$.

vi. Cek local buckling menggunakan Persamaan 7 dan Persamaan 8.

$$
\begin{aligned}
& \frac{b_{f}}{2 t_{f}} \leq 0,56 \sqrt{\frac{E}{f_{y}}} \\
& \frac{d-2 t_{f}}{t_{w}} \leq 1,49 \sqrt{\frac{E}{f_{y}}}
\end{aligned}
$$

halmana:

$b_{f} \quad=$ lebar elemen struktur [mm],

$t_{f} \quad=$ tebal sayap pada elemen [mm],

$t_{w}=$ tebal badan pada elemen [mm].

b. Menghitung Biaxial Bending

Untuk $\frac{P_{r}}{P_{c}} \geq 0,2$; menggunakan Persamaan 9.

$$
\frac{P_{r}}{P_{c}}+\frac{8}{9}\left(\frac{M_{r x}}{M_{c x}}+\frac{M_{r y}}{M_{c y}}\right) \leq 1,0
$$

Untuk $\frac{P_{r}}{P_{c}} \leq 0,2 ;$ menggunakan Persamaan 10.

$$
\frac{P_{r}}{2 P_{c}}+\left(\frac{M_{r x}}{M_{c x}}+\frac{M_{r y}}{M_{c y}}\right) \leq 1,0
$$

halmana:

$P_{r} \quad=$ kekuatan material yang butuhkan [N] (didapat dari output ETABS2015),

$P_{c} \quad=$ kekuatan desain material yang ada $[\mathrm{N}]$,

$M_{r} \quad=$ kekuatan momen yang dibutuhkan [Nmm] (didapat dari output ETABS2015),

$M_{c} \quad=$ kekuatan momen yang ada [Nmm].

3. Desain Balok Baja

Persyaratan untuk menghitung dimensi balok didasarkan pada SNI 1729:2015, persyaratan tersebut antara lain:

a. Syarat Lentur 
Struktur baja ini harus memenuhi syarat lentur yaitu, $Z_{x p e r l u}<Z_{x p r o f i l}$ dimana, $Z_{\text {xperlu }}$ dihitung dari Persamaan 11.

$$
Z_{x}=\frac{M_{n}}{f_{y}}
$$

halmana:

$M_{n} \quad=$ kekuatan lentur nominal pada penampang [Nmm],

$Z_{x} \quad=$ modulus plastisitas $\left[\mathrm{mm}^{3}\right]$.

b. Syarat Tekuk

Untuk menghindari tekuk yang terjadi pada baja maka perlu dicek dimana $L_{b} \leq L_{p}$, $L_{p}$ dapat dihitung menggunakan Persamaan 12.

$$
L_{p}=1,76 * r_{y} * \sqrt{\frac{E}{f_{y}}}
$$

halmana:

$L_{b} \quad=$ panjang bentang tidak tertekang terpanjang [mm],

$L_{p} \quad=$ Pembatasan panjang tidak breis secara lateral untuk kondisi batas leleh[mm],

$E \quad=$ modulus elastisitas baja [MPa],

$r_{y} \quad=$ jari-jari girasi penampang arah $y[\mathrm{~mm}]$.

c. Cek Penampang

Menurut Segui, W. T. (2013) untuk mengetahui penampang yang digunakan termasuk kedalam penampang kompak, non kompak atau langsing terdapat batasan sebagai berikut:

1. Jika $\lambda \leq \lambda_{\mathrm{p}}$, maka penampang kompak,

2. Jika $\lambda_{p}<\lambda \leq \lambda_{r}$, maka penampang non kompak,

3. Jika $\lambda>\lambda_{r}$, maka penampang langsing.

halmana:

$\lambda=$ rasio lebar ke tebal,

$\lambda_{\mathrm{p}} \quad=$ batas untuk kategori kompak,

$\lambda_{r} \quad=$ batas untuk kategori non kompak.

Pengecekan pada flange dan web dengan menggunakan persamaan-persamaan di bawah ini:

i. Cek local buckling pada web menggunakan Persamaan 13, Persamaan 14 dan Persamaan 15.

$$
\begin{aligned}
& \lambda=\frac{H-2 t_{f}}{t_{w}} \\
& \lambda_{p}=3,76 \sqrt{\frac{E}{f_{y}}} \\
& \lambda_{r}=5,70 \sqrt{\frac{E}{f_{y}}}
\end{aligned}
$$

ii. Cek local buckling pada flange menggunakan Persamaan 16, Persamaan 17 dan Persamaan 18. 


$$
\begin{aligned}
& \lambda=\frac{b_{f}}{2 t_{f}} \\
& \lambda_{p}=0,38 \sqrt{\frac{E}{f_{y}}} \\
& \lambda_{r}=1,0 \sqrt{\frac{E}{f_{y}}}
\end{aligned}
$$

iii. Untuk momen lentur pada penampang

Jika penampang kompak dihitung menggunakan Persamaan 19.

$$
M_{n}=M_{p}=f_{y} * Z_{x}
$$

- Jika penmpang non kompak dihitung menggunakan Persamaan 20.

$$
M_{n}=M_{p}-\left(M_{p}-0,7 f_{y} S_{x}\right) *\left(\frac{\lambda-\lambda_{p}}{\lambda_{r}-\lambda_{p}}\right)
$$

halmana:

$S_{x} \quad=$ modulus penampang $\left[\mathrm{mm}^{3}\right]$.

\subsection{Studi Terdahulu}

Penelitian ini disusun berdasarkan studi terdahulu yaitu oleh Ardian Alders Dhani (2015) dengan judul penelitian Analisis Pengaruh Perubahan Nilai Koefisien Modifikasi Respon $(R)$ Terhadap Perilaku Dinamis Struktur Gedung Tidak Beraturan. Penelitian ini menghasilkan kesimpulan nilai koefisien modifikasi respons sangat mempengaruhi kekakuan struktur, sehingga berpengaruh terhadap simpangan, dimana semakin besar nilai $\mathrm{R}$ semakin kecil simpangan yang terjadi.

Penelitian ini juga mengacu pada studi terdahulu yang disusun oleh Nazila Kamila Shaomi (2019) dengan judul penelitian Pembesaran Gaya Dalam dan Rasio Kekuatan Elemen Struktur Baja Untuk Berbagai Zona Gempa di Indonesia. Penelitian ini menghasilkan kesimpulan bahwa rasio minimum kolom pada daerah gempa frekuensi tinggi $\left(S_{1}=1,2 g\right)$ sebesar 0,39 dan rasio maksimum pada daerah gempa frekuensi rendah $\left(S_{1}=0,2 g\right)$ sebesar 0,9 .

\section{METODOLOGI PENELITIAN}

Pada penelitian tugas akhir ini akan dilakukan analisis pembesaran gaya dalam dan rasio kekuatan untuk elemen struktur baja untuk berbagai koefisien modifikasi respon. Tahap awal yang dilakukan ialah mengumpulkan data dan kepustakaan terkait yang menunjang penelitian. Kemudian melakukan preliminary design untuk elemen struktur. Selanjutnya mendesain dimensi elemen SRPMB untuk nilai $R=3$ dan 3,5; SRPMM untuk nilai $R=4,5$ dan 5 dan SRPMK untuk nilai $R=6,7$ dan 8 dengan pengecekan menggunakan ETABS2015. Kombinasi pembebanan yang digunakan pada penelitian ini menggunakan metode LRFD (Load And Resistance Factor Design). Hasil output dari software ETABS2015 yaitu berupa data gaya dalam dan rasio yang kemudian dianalisis berdasarkan pembesaran gaya dalam dan rasio kekuatan untuk berbagai nilai koefisien modifikasi respon $(R)$. Bagan alir penelitian tugas akhir ini dapat dilihat pada Gambar 2. 


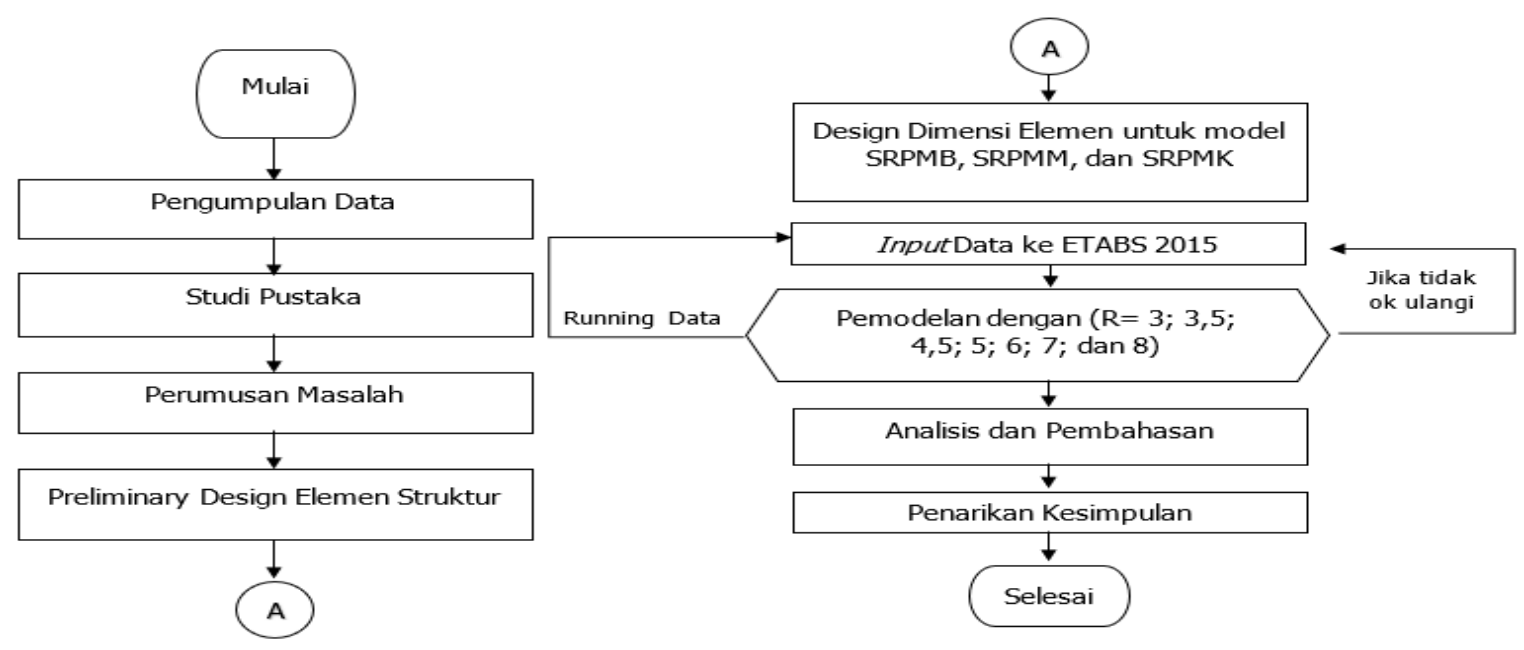

Gambar 2. Bagan alir penelitian

\section{ANALISIS DAN PEMBAHASAN}

\subsection{Preliminary Design}

Preliminary design ini dilakukan sebagai acuan untuk tahap selanjutnya pada saat pemodelan struktur yang akan dianalisis menggunakan software ETABS2015. Pada tahap ini dihasilkan dimensi untuk balok dan kolom yang dapat dilihat pada Tabel $\mathbf{1}$ dan Tabel $\mathbf{2}$.

Tabel 1. Profil Balok yang Digunakan pada Penelitian

\begin{tabular}{cc}
\hline $\begin{array}{c}\text { Bentang } \\
{[\mathbf{m}]}\end{array}$ & $\begin{array}{c}\text { Profil IWF untuk Balok Komposit } \\
\text { (Pemodelan SRPMB, SRPMM, dan SRPMK) }\end{array}$ \\
\hline 2 & $150 \times 75 \times 5 \times 7$ \\
\hline 4 & $350 \times 350 \times 12 \times 19$ \\
\hline 6 & $500 \times 200 \times 9 \times 14$ \\
\hline 7,2 & $600 \times 200 \times 11 \times 17$ \\
\hline 8 & $588 \times 300 \times 12 \times 20$ \\
\hline
\end{tabular}

Tabel 2. Profil Kolom yang Digunakan pada Penelitian

\begin{tabular}{cc}
\hline Lantai & $\begin{array}{c}\text { Profil IWF untuk Kolom } \\
\text { (Pemodelan SRPMB, SRPMM, dan SRPMK) }\end{array}$ \\
\hline 1 & $800 \times 500 \times 21 \times 38$ \\
\hline 2 & $800 \times 500 \times 21 \times 38$ \\
\hline 3 & $700 \times 440 \times 21 \times 38$ \\
\hline 4 & $700 \times 440 \times 21 \times 38$ \\
\hline 5 & $700 \times 390 \times 21 \times 33$ \\
\hline 6 & $700 \times 390 \times 21 \times 33$ \\
\hline 7 & $700 \times 380 \times 18 \times 25$ \\
\hline 8 & $700 \times 380 \times 18 \times 25$ \\
\hline 9 & $700 \times 310 \times 25 \times 18$ \\
\hline 10 & $700 \times 310 \times 25 \times 18$ \\
\hline
\end{tabular}

\subsection{Pembebanan}

Beban yang digunakan pada penelitian ini adalah sebagai berikut:

1. Beban mati

Beban mati yang digunakan pada penelitian ini yaitu beban dinding, lantai, plafon, beban ME (Mechanical Electrical) dan lain-lain. 
2. Beban hidup

Beban hidup yang digunakan sesuai dengan fungsi gedung yaitu perkantoran yang dapat dilihat di dalam SNI 1727:2013 seperti pada Tabel 3.

Tabel 3. Beban Hidup yang Digunakan dalam Penelitian

\begin{tabular}{ccc}
\hline Hunian atau penggunaan & $\begin{array}{c}\text { Merata } \\
\boldsymbol{p s} \boldsymbol{f}\left[\boldsymbol{k N} / \boldsymbol{m}^{2}\right]\end{array}$ & $\begin{array}{c}\text { Terpusat } \\
\boldsymbol{l b}[\boldsymbol{k N}]\end{array}$ \\
\hline $\begin{array}{c}\text { Gedung perkantoran: } \\
\text { Ruang arsip dan komputer harus dirancang untuk beban } \\
\text { Yang lebih berat berdasarkan pada perkiraan hunian } \\
\text { Lobi dan koridor lantai pertama }\end{array}$ & \\
Kantor & $100(4,79)$ & $2.000(8,90)$ \\
Koridor & $50(2,40)$ & $2.000(8,90)$ \\
& $80(3,83)$ & $2.000(8,90)$ \\
\hline
\end{tabular}

(Sumber: Badan Standardisasi Nasional, 2013)

3. Beban gempa

Beban gempa yang digunakan dalam penelitian ini diperoleh dari http://puskim.pu.go.id/Aplikasi/desain spektra indonesia 2011/. Besarnya percepatan respon spektrum pada periode 1 detik $\left(S_{1}\right)$ yang digunakan ialah $0,6 \mathrm{~g}$.

\subsection{Analisis Kolom dan Balok}

Kolom dan balok yang ditinjau pada penelitian ini dapat dilihat pada Gambar 3. Hasil output dari analisis ETABS2015 untuk kolom dan balok dapat dilihat pada Tabel 4. Kemudian dilakukan perbandingan relatif dan absolut untuk melihat pembesaran yang terjadi akibat perubahan nilai koefisien modifikasi respon $(R)$ dapat dilihat pada Tabel 5 dan Tabel 6, serta grafik perbandingan absolut yang dapat dilihat pada Gambar $\mathbf{4}$ dan Gambar 5. Hasil perhitungan terhadap rasio geser dan lentur dapat dilihat pada Tabel 7 dan Tabel 8.
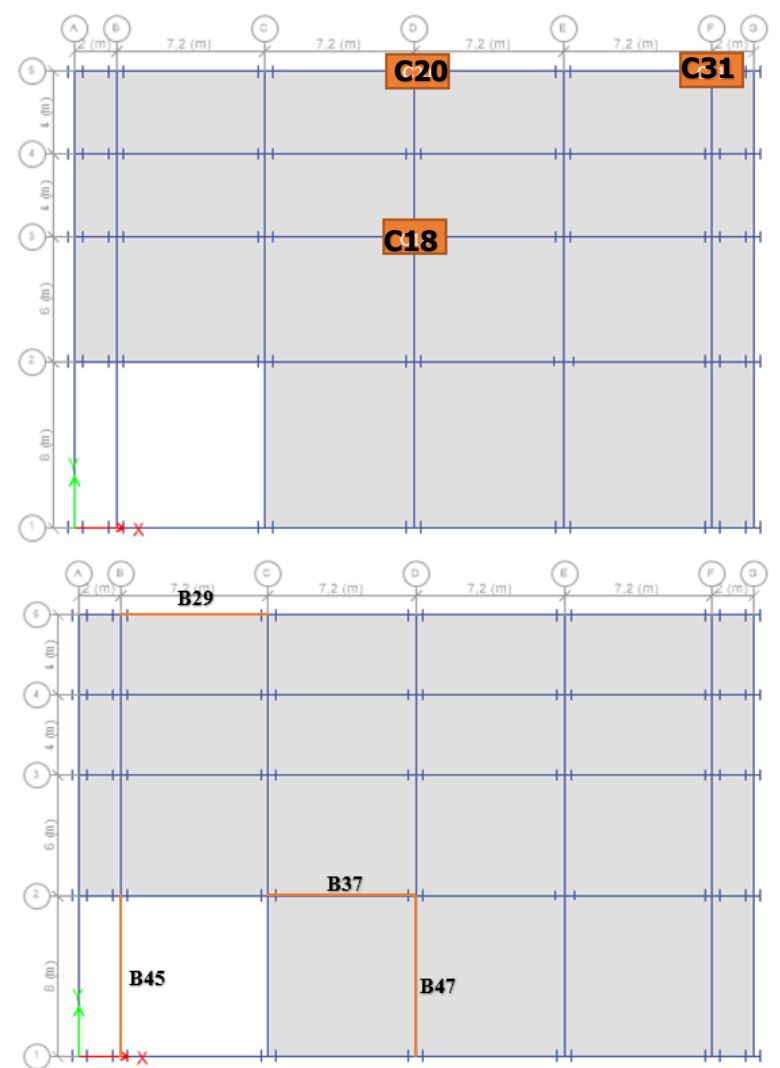

Gambar 3. Kolom dan balok yang dianalisis dalam penelitian 
Tabel 4. Hasil Output Gaya Dalam pada Kolom 18 (C18) dan Balok 29 (B29)

\begin{tabular}{|c|c|c|c|c|c|c|c|c|}
\hline \multirow{2}{*}{ Label dalam ETABS2015 } & \multirow{2}{*}{ Gaya Dalam } & \multicolumn{7}{|c|}{ Koefisien Modifikasi Respon $(R)$} \\
\hline & & 8 & 7 & 6 & 5 & 4,5 & 3,5 & 3 \\
\hline \multirow{6}{*}{$\mathrm{C} 18$} & $\mathrm{P}[\mathrm{kN}]$ & 4288,01 & 4310,58 & 4339,28 & 4373,01 & 4398,20 & 4482,80 & 4524,13 \\
\hline & V2 [kN] & 28,42 & 33,11 & 38,62 & 45,43 & 50,47 & 66,14 & 75,67 \\
\hline & V3 [kN] & 74,79 & 88,65 & 101,84 & 114,31 & 126,02 & 167,80 & 184,56 \\
\hline & $\mathrm{T}[\mathrm{kN}-\mathrm{m}]$ & 0,03 & 0,03 & 0,04 & 0,05 & 0,06 & 0,07 & 0,09 \\
\hline & $\mathrm{M} 2[\mathrm{kN}-\mathrm{m}]$ & 173,35 & 214,45 & 248,01 & 270,01 & 298,65 & 415,83 & 441,85 \\
\hline & $\mathrm{M} 3[\mathrm{kN}-\mathrm{m}]$ & 125,46 & 159,95 & 186,51 & 200,43 & 222,64 & 319,35 & 333,70 \\
\hline \multirow{6}{*}{ B29 } & $\mathrm{P}[\mathrm{kN}]$ & 0,000 & 0,000 & 0,000 & 0,000 & 0,000 & 0,000 & 0,000 \\
\hline & V2 [kN] & 113,846 & 114,857 & 121,497 & 136,908 & 143,741 & 154,699 & 177,906 \\
\hline & $\mathrm{V} 3[\mathrm{kN}]$ & 0,000 & 0,000 & 0,000 & 0,000 & 0,000 & 0,000 & 0,000 \\
\hline & $\mathrm{T}[\mathrm{kN}-\mathrm{m}]$ & 0,108 & 0,117 & 0,128 & 0,142 & 0,152 & 0,181 & 0,201 \\
\hline & $\mathrm{M} 2[\mathrm{kN}-\mathrm{m}]$ & 0,000 & 0,000 & 0,000 & 0,000 & 0,000 & 0,000 & 0,000 \\
\hline & M3 [kN-m] & 177,047 & 180,569 & 197,935 & 237,220 & 255,050 & 284,764 & 344,195 \\
\hline
\end{tabular}

Tabel 5. Perbandingan Relatif Nilai Gaya Dalam pada Kolom dan Balok berdasarkan Output ETABS2015 pada Kolom 18 (C18) dan Balok 29 (B29)

\begin{tabular}{|c|c|c|c|c|c|c|c|}
\hline \multirow[b]{2}{*}{ Label dalam ETABS2015 } & \multirow[b]{2}{*}{ Gaya Dalam } & \multicolumn{6}{|c|}{ Rasio Koefisien Modifikasi Respons $(R)$ untuk Nilai $R$ tertentu } \\
\hline & & $\begin{array}{c}8 \text { terhadap } \\
7\end{array}$ & $\begin{array}{c}7 \\
\text { terhadap } \\
6\end{array}$ & $\begin{array}{c}6 \\
\text { terhadap } \\
5 \\
\end{array}$ & $\begin{array}{c}\mathbf{5} \\
\text { terhadap } \\
4,5 \\
\end{array}$ & $\begin{array}{c}4,5 \\
\text { terhadap } \\
3,5 \\
\end{array}$ & $\begin{array}{c}3,5 \\
\text { terhadap } \\
3 \\
\end{array}$ \\
\hline \multirow{6}{*}{$\begin{array}{c}\text { C18 } \\
\text { (Kolom) }\end{array}$} & $\mathrm{P}[\mathrm{kN}]$ & 1,005 & 1,007 & 1,008 & 1,006 & 1,019 & 1,009 \\
\hline & V2 [kN] & 1,165 & 1,166 & 1,176 & 1,111 & 1,311 & 1,144 \\
\hline & V3 $[\mathrm{kN}]$ & 1,185 & 1,149 & 1,122 & 1,102 & 1,332 & 1,100 \\
\hline & $\mathrm{T}[\mathrm{kN}-\mathrm{m}]$ & 1,062 & 1,166 & 1,282 & 1,109 & 1,198 & 1,247 \\
\hline & $\mathrm{M} 2[\mathrm{kN}-\mathrm{m}]$ & 1,237 & 1,157 & 1,089 & 1,106 & 1,392 & 1,063 \\
\hline & M3 [kN-m] & 1,275 & 1,166 & 1,075 & 1,111 & 1,434 & 1,045 \\
\hline \multirow{6}{*}{$\begin{array}{l}\text { B29 } \\
\text { (Balok) }\end{array}$} & $\mathrm{P}[\mathrm{kN}]$ & 1,000 & 1,000 & 1,000 & 1,000 & 1,000 & 1,000 \\
\hline & V2 [kN] & 1,009 & 1,058 & 1,127 & 1,050 & 1,076 & 1,150 \\
\hline & V3 [kN] & 1,000 & 1,000 & 1,000 & 1,000 & 1,000 & 1,000 \\
\hline & $\mathrm{T}[\mathrm{kN}-\mathrm{m}]$ & 1,078 & 1,092 & 1,112 & 1,070 & 1,193 & 1,112 \\
\hline & $\mathrm{M} 2[\mathrm{kN}-\mathrm{m}]$ & 1,000 & 1,000 & 1,000 & 1,000 & 1,000 & 1,000 \\
\hline & M3 [kN-m] & 1,020 & 1,096 & 1,198 & 1,075 & 1,117 & 1,209 \\
\hline
\end{tabular}

Tabel 6. Perbandingan Absolut Nilai Gaya Dalam pada Kolom dan Balok berdasarkan Output ETABS2015 pada Kolom 18 (C18) dan Balok 29 (B29)

\begin{tabular}{|c|c|c|c|c|c|c|c|c|}
\hline \multirow[b]{2}{*}{$\begin{array}{l}\text { Label dalam } \\
\text { ETABS2015 }\end{array}$} & \multirow[b]{2}{*}{ Gaya Dalam } & \multicolumn{7}{|c|}{ Rasio Koefisien Modifikasi Respons $(R)$ untuk Nilai $R$ tertentu } \\
\hline & & $\begin{array}{c}8 \\
\text { terhadap } \\
8\end{array}$ & $\begin{array}{c}8 \\
\text { terhadap } \\
7\end{array}$ & $\begin{array}{c}8 \\
\text { terhadap } \\
6\end{array}$ & $\begin{array}{c}8 \\
\text { terhadap } \\
5\end{array}$ & $\begin{array}{c}8 \\
\text { terhadap } \\
4,5\end{array}$ & $\begin{array}{c}8 \\
\text { terhadap } \\
3,5\end{array}$ & $\begin{array}{c}8 \\
\text { terhadap } \\
3\end{array}$ \\
\hline \multirow{6}{*}{$\begin{array}{c}\text { C18 } \\
\text { (Kolom) }\end{array}$} & $\mathrm{P}[\mathrm{kN}]$ & 1,000 & 1,005 & 1,012 & 1,020 & 1,026 & 1,045 & 1,055 \\
\hline & $\mathrm{V} 2[\mathrm{kN}]$ & 1,000 & 1,165 & 1,359 & 1,599 & 1,776 & 2,328 & 2,663 \\
\hline & V3 [kN] & 1,000 & 1,185 & 1,362 & 1,528 & 1,685 & 2,244 & 2,468 \\
\hline & $\mathrm{T}[\mathrm{kN}-\mathrm{m}]$ & 1,000 & 1,062 & 1,238 & 1,586 & 1,759 & 2,108 & 2,630 \\
\hline & $\mathrm{M} 2$ [kN-m] & 1,000 & 1,237 & 1,431 & 1,558 & 1,723 & 2,399 & 2,549 \\
\hline & M3 [kN-m] & 1,000 & 1,275 & 1,487 & 1,598 & 1,775 & 2,545 & 2,660 \\
\hline \multirow{6}{*}{$\begin{array}{c}\text { B29 } \\
\text { (Balok) }\end{array}$} & $\mathrm{P}[\mathrm{kN}]$ & 1,000 & 1,000 & 1,000 & 1,000 & 1,000 & 1,000 & 1,000 \\
\hline & $\mathrm{V} 2[\mathrm{kN}]$ & 1,000 & 1,009 & 1,067 & 1,203 & 1,263 & 1,359 & 1,563 \\
\hline & V3 [kN] & 1,000 & 1,000 & 1,000 & 1,000 & 1,000 & 1,000 & 1,000 \\
\hline & $\mathrm{T}[\mathrm{kN}-\mathrm{m}]$ & 1,000 & 1,078 & 1,177 & 1,309 & 1,401 & 1,671 & 1,859 \\
\hline & $\mathrm{M} 2$ [kN-m] & 1,000 & 1,000 & 1,000 & 1,000 & 1,000 & 1,000 & 1,000 \\
\hline & M3 [kN-m] & 1,000 & 1,020 & 1,118 & 1,340 & 1,441 & 1,608 & 1,944 \\
\hline
\end{tabular}

Berdasarkan tabel relatih kita dapat melihat pembesaran yang terjadi dengan membandingkan nilai $R$ yang bernilai besar terhadap nilai $R$ yang bernilai kecil dimana untuk kolom 18 nilai relatif terbesar pada momen adalah 1,434 dan untuk balok 29 nilai relatif terbesar pada momen adalah 1,209. Berdasrkan tabel absolut kita dapat melihat pembesaran yang terjadi akibat perubahan nilai koefisien modifikasi respon $(R)$, dimana $R=8$ 
dijadikan acuan sebagai pembanding, kita dapat lihat bahwa semakin kecil nilai $R$ yang digunakan maka semakin besar rasio gaya dalam yang dihasilkan.

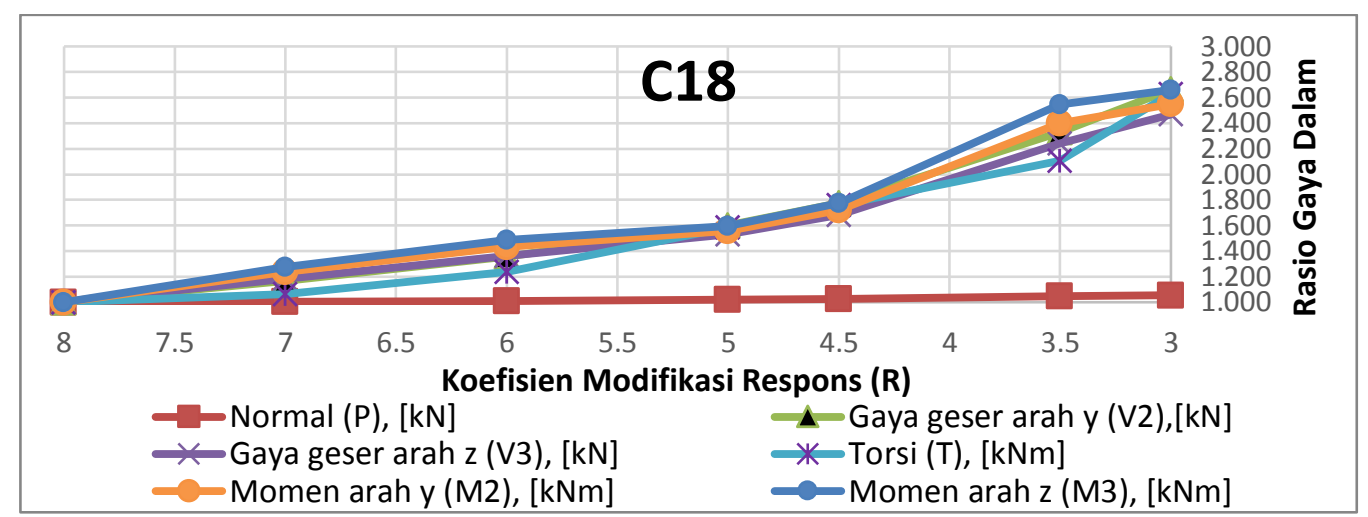

Gambar 4. Grafik hubungan antara nilai koefisien modifikasi respons $(R)$ terhadap rasio gaya dalam pada kolom 18 (C18)

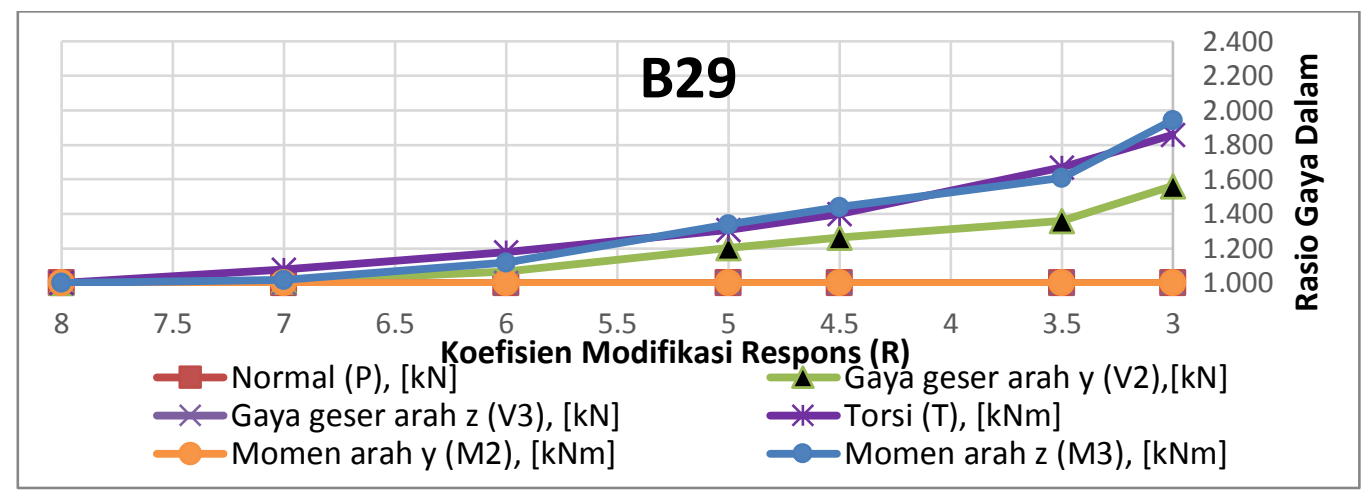

Gambar 5. Grafik hubungan antara nilai koefisien modifikasi respon $(R)$ terhadap rasio gaya dalam pada balok (B29)

Berdasarkan grafik diatas kita dapat melihat rasio pembesaran yang terjadi akibat perubahan nilai koefisien modifikasi respon $(R)$, baik gaya dalam normal, momen, geser dan torsi.

Tabel 7. Nilai Rasio Lentur dan Geser pada Kolom (C18)

\begin{tabular}{cccc}
\hline $\begin{array}{c}\text { Koefisien } \\
\text { Modifikasi } \\
\text { Respon( } \boldsymbol{R})\end{array}$ & \multicolumn{2}{c}{$\boldsymbol{r}_{\text {geser }}$} & \\
\cline { 2 - 3 } & Arah $\boldsymbol{x}$ & Arah $\boldsymbol{y}$ & $\boldsymbol{r}_{\text {lentur }}$ \\
\hline 8 & 0,026 & 0,010 & 0,425 \\
\hline 7 & 0,030 & 0,011 & 0,459 \\
\hline 6 & 0,035 & 0,013 & 0,486 \\
\hline 5 & 0,039 & 0,016 & 0,505 \\
\hline 4,5 & 0,043 & 0,017 & 0,529 \\
\hline 3,5 & 0,057 & 0,023 & 0,626 \\
\hline 3 & 0,063 & 0,026 & 0,648 \\
\hline
\end{tabular}

Catatan: $r=$ rasio

Tabel 8. Nilai Rasio Lentur dan Geser pada Balok 29 (B29)

\begin{tabular}{cccccccc}
\hline \multirow{2}{*}{ Label dalam ETABS2015 } & \multicolumn{7}{c}{ Koefisien Modifikasi Respons $(\boldsymbol{R})$} \\
\cline { 2 - 8 } & $\mathbf{8}$ & $\mathbf{7}$ & $\mathbf{6}$ & $\mathbf{5}$ & $\mathbf{4 , 5}$ & $\mathbf{3 , 5}$ & $\mathbf{3}$ \\
\hline Balok 29 (rasio lentur) & 0,213 & 0,217 & 0,238 & 0,286 & 0,307 & 0,343 & 0,415 \\
\hline Balok 29 (rasio geser) & 0,099 & 0,100 & 0,106 & 0,119 & 0,125 & 0,135 & 0,155 \\
\hline
\end{tabular}


Berdasarkan hasil output ETABS2015 dan perhitungan yang telah dilakukan dapat kita lihat perbesaran rasio lentur pada kolom 18 dimana ketika nilai modifikasi respon $R=3$ sebesar 0,648 dan perbesaran rasio lentur pada balok 29 ketika $R=3$ sebesar 0,415.

\section{KESIMPULAN DAN SARAN}

\subsection{Kesimpulan}

Berdasarkan penelitian yang telah dilakukan dapat disimpulkan beberapa hal sebagai berikut:

1. Semakin kecil nilai koefisien modifikasi respons $R$ yang digunakan mempengaruhi rasio geser yang terjadi. perbesaran nilai geser arah $x$ pada kolom 18 (C18) ketika nilai $R=3$ sebesar $142,3 \%$ dan nilai geser arah y sebesar $160 \%$.

2. Perubahan nilai koefisien modifikasi respons juga berpengaruh terhadap perbesaran rasio lentur semakin kecil nilai $R$ semakin besar pula rasio lentur yang terjadi. Perbesaran rasio geser pada kolom 18 (C18) ketika $R=3$ sebesar $52,47 \%$.

3. Perubahan nilai $R$ juga berpengaruh pada rasio lentur dan geser pada balok. Perbesaran lentur yang terjadi pada balok 29 (B29) ketika nilai $R=3$ sebesar $94,84 \%$ dan perbesaran geser yang terjadi sebesar $56,56 \%$.

\subsection{Saran}

Saran yang dapat penulis berikan untuk penelitian selanjutnya mengenai analisa pembesaran gaya dalam dan kekuatan rasio adalah sebagai berikut:

1. Menggunakan beberapa program pendukung seperti tekla untuk mendapatkan beban yang lebih akurat.

2. Melakukan analisis pushover untuk mendapatkan nilai daktilitas, dan dimana letak terjadinya sendi plastis, dan nilai koefisien modifikasi respons $R$ yang sebenarnya.

\section{DAFTAR RUJUKAN}

Ardian, A. D. (2015). Analisis Pengaruh Perubahan Nilai Koefisien Modifikasi Respon (R) terhadap Perilaku Dinamis Struktur Gedung Tidak Beraturan. Yogyakarta: Jurusan Teknik Sipil - Universitas Gadjah Mada.

Badan Standardisasi Nasional. (2012). SNI 1726:2012 tentang Tata Cara Ketahanan Gempa untuk Struktur Bangunan Gedung dan Non Gedung. Jakarta: Badan Standardisasi Nasional.

Badan Standardisasi Nasional. (2013). SNI 1727:2013 tentang Beban Minimum untuk Perancangan Bangunan Gedung dan Struktur Lain. Jakarta: Badan Standardisasi Nasional.

Badan Standardisasi Nasional. (2013). SNI 2847:2013 tentang Persyaratan Beton Struktural untuk Bangunan Gedung. Jakarta: Badan Standardisasi Nasional.

Badan Standardisasi Nasional. (2015). SNI 1729:2015 tentang Spesifikasi untuk Bangunan Gedung Baja Struktural. Jakarta: Badan Standardisasi Nasional.

Pusat Penelitian dan Pengembangan Permukiman - Kementerian Pekerjaan Umum. (2019, Agustus 1). Peta Google. Dipetik Agustus 1, 2019, from Desain Spektra Indonesia: http://puskim.pu.go.id/Aplikasi/desain_spektra_indonesia_2011/

Segui, W. T. (2012). Steel Design $5^{\text {th }}$ Edition. Stamford: Cengage Learning.

Shaomi, N. K. (2019). Pembesaran Gaya Dalam dan Rasio Kekuatan Elemen Struktur. Tugas Akhir. Bandung: Jurusan Teknik Sipil - Institut Teknologi Nasional - Bandung. 